Article

\title{
Analysis of the Internal Relationship between Ecological Value and Economic Value Based on the Forest Resources in China
}

\author{
Jianxin Geng and Chengzhi Liang *
}

check for updates

Citation: Geng, J.; Liang, C. Analysis of the Internal Relationship between Ecological Value and Economic Value Based on the Forest Resources in China. Sustainability 2021, 13, 6795. https://doi.org/10.3390/su13126795

Academic Editors: Sharif

Ahmed Mukul and Antonio Boggia

Received: 30 April 2021

Accepted: 13 June 2021

Published: 16 June 2021

Publisher's Note: MDPI stays neutral with regard to jurisdictional claims in published maps and institutional affiliations.

Copyright: (c) 2021 by the authors. Licensee MDPI, Basel, Switzerland. This article is an open access article distributed under the terms and conditions of the Creative Commons Attribution (CC BY) license (https:// creativecommons.org/licenses/by/ $4.0 /)$.
School of Business, Renmin University of China, Beijing 100000, China; gengjianxin@rmbs.ruc.edu.cn

* Correspondence: 2016100983@ruc.edu.cn

\begin{abstract}
In this study, we applied gross ecosystem product (GEP) theory in a case study to analyze and explain the natural resource asset value and ecosystem service value of forest resources in Jiaokou County, Shanxi Province, Northern China, in 2018. GEP refers to the total value of various final material products and services provided by ecosystems. In this paper, six service functions of a forest system, including water conservation, soil conservation, carbon fixation and oxygen release, forest nutrients, purification of atmospheric environment, and biodiversity, are valued by three calculation methods: the alternative cost method, market value method, and control cost method. The study revealed the following: (1) There is a parallel relationship between the value of natural resource assets and the value of ecosystem services. GEP includes the market value of natural resource assets, but it is mostly the value of ecosystem services. (2) The measurement of the physical quantity of forest ecosystem services depends on parameter data, and the monetary calculation often has no mature pricing basis, which leads to the large scale and uncertainty surrounding the evaluation results of ecosystem services. (3) The ecosystem service value and natural resource asset value have different practical significance, as well as alternate theoretical bases. The value of natural resource assets can be used as the asset valuation basis of economic transactions, which plays a role in macroeconomic management. The value of ecosystem services can be used as the basis of ecological compensation, providing information for the preparation of the balance sheet of natural resources.
\end{abstract}

Keywords: forest ecosystem value; balance sheet of natural resources; environmental and economic accounting

\section{Introduction}

\subsection{Two Important Value Accounting Foundations}

The aggravation of ecological and environmental problems has become a significant threat to sustainable economic and social development, as well as human living conditions globally. Global environmental researchers proposed the concept of ecosystem service evaluation in the 1970s in an effort to raise people's awareness regarding the importance of ecosystems and promote the integration of the value of ecosystems into economic decision making. In the following decades, environmental researchers around the world conducted extensive discussions regarding the concept, connotation, and scope for assessing ecosystem services. In 1995, more than 30 environmental experts from the Pew Research Center created a book on ecosystem services entitled Natural Services: Society's Dependence on Natural Ecosystems. In 1996, the World Ecosystem Services and Natural Capital Values workshop was established at the National Center for Ecological Analysis and Research in the United States, which was dedicated to assessing the capital value of ecosystems.

Based on theoretical discussion, the concept of gross ecosystem product (GEP), or ecosystem value, has been commonly accepted. Below, the ecosystem values are collectively referred to as GEP. GEP includes both economic value and ecological value. This incorporates the total value of products and services provided by ecosystems to human beings. The ecosystems include: forest ecosystem, wetland ecosystem, grassland ecosystem, 
desert ecosystem, ocean ecosystem, farmland ecosystem, and city ecosystem. Among them, ecosystem products are traditional economic crops, such as felled trees, caught fish, etc. The valuation of economic products generally has a mature theoretical basis and market price reference, whereas ecological services are diverse and difficult to evaluate.

In 2012, the United Nations Statistical Commission issued the System of EnvironmentalEconomic Accounting (SEEA2012) to provide a unified foundation and standard for the accounting of ecosystem products and services. The measurement basis of SEEA2012 is attached to the existing System of National Accounts (SNA). SNA refers to a statistical framework that provides a comprehensive, consistent, and flexible macroeconomic account for decision making, analysis, and research issued by the United Nations. However, the relationship between ecosystem value (GEP) and value used by System of National Accounts (SNA) or System of Environmental-Economic Accounting (SEEA) entails remains unclear.

\subsection{Research Background in China}

Since China's opening to global trade and markets, economic development has occurred at costs to the environment and its resources. Many researchers are studying environment protection. However, the important question remains: should the ecological compensation system and the natural resource balance sheet use the same kind of value? How should the value of natural resource assets and the value of ecosystem services be understood and explained?

The ecological compensation system, or the ecological compensation mechanism, is one institutional arrangement that uses administrative and market means to adjust ecological environmental protection and build the interests of relevant parties [1]. Additionally, the natural resource balance sheet, which is currently under preparation in China, describes requirements for the definition of value of natural resources. The accounting of ecosystem values is the basis for such practices.

We selected a case study of forest resources evaluation in Jiaokou County, Shanxi Province, Northern China, for analyzing the relationship between the economic value and ecological value of natural resources, namely the relationship between the value of natural resource assets and the value of ecosystem services. The study findings provide experience and reference for ecological protection practice in China and other countries.

\section{Literature Review}

\subsection{Exploration and Classification of Service Concepts for Ecosystem Values}

The concept of services in ecosystem values began in the 1970s. Westman [2] first mentioned the concept of ecosystem services using the term "nature services". From the perspective of maximizing economic benefits and utility, researchers proposed the idea of monetizing "natural services" and incorporating them into economic decision making. Paul and Harold [3] further elaborated on ecosystem services, including the mechanisms by which ecosystem services act on human societies. Braat [4] stated that the value of all things in the world is related to being beneficial to human beings. This is an anthropocentric philosophy, and the ecological environment system was no exception; therefore, only products and services that were beneficial to human beings in ecosystems were considered valuable, and such value can often only be measured by currency.

The classification of service concepts in ecosystem values was first seen in the 1990s. Daily [5] divided the ecosystem services system into 13 categories, whereas Costanza [6] divided them into 17 categories. In 2001, the Millennium Ecosystem Assessment (MEA) program of the United Nations Environment Programme (UNEP) was officially launched. The assessment report divided ecosystem services into four broad categories with 18 specific categories. The classification of the MEA system has become the authoritative standard for classifying ecosystem services in ecology. Table 1 shows the classification structure of the MEA. 
Table 1. A summary of the ecosystem service classification of the Millennium Ecosystem Assessment system.

\begin{tabular}{|c|c|c|c|}
\hline Category & Content & Category & Content \\
\hline \multirow{5}{*}{ Supply Service } & Producing food & \multirow{3}{*}{ Management Service } & Soil erosion control and soil formation \\
\hline & Production of fresh water & & Plant pollination \\
\hline & Production of fiber & & $\begin{array}{l}\text { Pest management and human } \\
\text { disease control }\end{array}$ \\
\hline & $\begin{array}{l}\text { Provide ornamental resources and } \\
\text { genetic resources }\end{array}$ & \multirow{2}{*}{ Support Service } & Nutrient cycling and photosynthesis \\
\hline & Provide biochemicals and natural medicines & & Protecting biodiversity \\
\hline \multirow{4}{*}{ Management Service } & Air quality regulation and climate regulation & \multirow{4}{*}{ Cultural Service } & Provide entertainment and ecotourism value \\
\hline & Natural disaster regulation & & $\begin{array}{l}\text { Provide aesthetic value and protect } \\
\text { cultural diversity }\end{array}$ \\
\hline & $\begin{array}{l}\text { Irrigation and flood control and other water } \\
\text { source management }\end{array}$ & & Provide spiritual and religious values \\
\hline & Water purification and waste treatment & & $\begin{array}{l}\text { Provide knowledge value and } \\
\text { educational value }\end{array}$ \\
\hline
\end{tabular}

\subsection{International and Domestic Exploration of the Value of Quantitative Ecosystem Services}

The economists Pigou and Coase have proposed famous economic theories, namely, the Pigou tax theory and the Coase theorem, regarding how to reduce the externalities of the economy on the ecosystem. Pigou's proposal for correcting externalities requires the government to revise the private costs of economic parties through taxation or subsidies. As long as the government implements measures to ensure private costs and private benefits are equal to the corresponding social costs and social benefits, resource allocation shall automatically reach Pareto optimality. Coase suggested that as long as the government clearly defines property rights, it shall use market mechanisms to exchange property rights and effectively solve economic externalities.

International discussion of the monetization and commercialization of ecosystem services began in the 1990s. Costanza (1997), based on 1996 National Center for Ecological Analysis and Research (NCEAS) research, summarized the calculation methods of ecosystem value and assessed 17 ecosystems across the world. Stavins [7] stated that prior to the value of ecosystem services being quantified, public sectors can only manage environmental problems by administrative means, and the so-called Pigou tax theory cannot be effectively implemented. Balmford [8] thought that the value of ecosystem services is the opportunity cost in the absence of economic development. Bayon [9] conducted a study on the U.S. Clean Water Act of 1972. Bayon suggested the assessment mechanism for the value of wetland ecosystem services can be found in the various needs of the Engineering Corps for the various services provided by wetland ecosystems. The average compensation price for wetland development in the United States reached USD 7356 per acre, according to a survey conducted by the U.S. Court of Auditors. In the Environmental Services Payments Program (PES), Wunder [10] noted that a payment mechanism for ecological service fees exists between at least one demander and one producer. However, monopolistic buyers and producers are widespread. For example, other nature reserves cannot use the services provided by a nature reserve for biodiversity conservation. Therefore, the market for ecological services was often imperfect.

Clarkson [11], Mitsch and Gosselink [12], Mitsch [13], Mondal [14], and Shi [15] used the cost analysis method in evaluating wetland ecosystem services, which included groundwater recharge, flood storage, water quality amelioration and enhancement, carbon storage, wildlife habitat, recycling of organic waste, and fisheries. Brown [16], Kaplan and Kaplan [17], Chaudhry [18], and Wu and Plantinga [19] used the shadow price method for evaluating urban ecosystem services, which included climate and air quality improvement, pollination, carbon sequestration, etc. 
With the exception of the cost analysis and shadow price methods, other methods have also been commonly accepted. Haipeng and Xuxuan [20], Louviere and Hensher [21], Louviere and Woodworth [22], Boxall [23], Taylor and Longo [24], Álvarez-Farizo [25], Hoehn [26], Broadbent [27], Vollmer [28], Hainmueller [29], Hanley [30], and Stevens [31] determined choice experiments and the contingent valuation method to be feasible tools for the valuation of ecosystem services. The theory of stated preference that was proposed by Fioramonti [32] relies on consumers' reactions to the hypothetical ecological services trading market, contingent value, and structured choice experiments. Its pricing is based on experiments. Kent [33] divided and compared the real estate data according to the distance from forest parks and used the regression coefficient to capture the marginal value of various ecosystem services by establishing a logarithmic hedonic price model. Boumans [34] explored the application of a multi-scale integrated ecosystem services model (MIME) in assessing the value of ecosystem services using global land, freshwater, and marine cases. Schmidt [35] proposed a transfer function model of global ecological service value based on the analysis of 194 cases involving 839 monetary value indicators.

Similar to other methods mentioned above, the pricing of ecosystem services that were discussed by Schmidt (2016) was also determined according to the expense method. Divya [36] used the total budget of the property company as the total value of the park ecosystem and then conducted a satisfaction survey on the convenience, safety, green area, and other aspects of the park. Divya analyzed the impact of different characteristics of the park ecosystem on the total value through linear regression. Lilei [37] evaluated the cultural services of two wetland national parks in Chongqing. David [38] evaluated the social value of the Dublin Bay ecosystem, including swimming, surfing, artistic creation, and other activities that are directly related to the bay. Differently from other researchers, David (2020) continued to conduct a questionnaire survey for a long time, which provided incremental information for the evaluation of ecosystem service value in the time dimension.

The pricing methods of ecosystem services discussed by international researchers provided an important reference for Chinese ones. Chinese researchers have learned from the experience of international researchers in relation to the pricing methods of ecosystem services.

From a domestic perspective, at the municipal level, Wang [39] assessed Aershan City, Inner Mongolia, using the market value method, shadow engineering method, alternative cost method, and tourism cost method to measure the values of ecosystem products and cultural services. The assessment results show that the total ecosystem production value (GEP) of Aershan City was USD 8.38 billion in 2014, which was 32 times the city's GDP in that year, with the forest ecosystem production value being USD 5.20 billion dollars and accounting for $61.99 \%$ of the GEP. Baima [40] conducted a value assessment of the products, adjustment services, and cultural services of the Ganzi Prefecture ecosystem in Sichuan Province. The evaluation results show that Gansu Prefecture's 2010 statewide ecosystem production (GEP) was USD 117,183.01 million, USD 1.11 million per capita, which equated to approximately 61 times the state's gross domestic product (GDP) and per capita GDP. Jin [41] used the energy analysis theory to calculate the GEP values of Xuzhou City, Jiangsu Province, in 2011 based on the specific formula. Jin et al. converted energy from all ecosystems in Xuzhou and converted the obtained energy base data into solar energy data, which were then divided by the energy/currency ratio to obtain the monetary value of each ecosystem. The research results show that the GEP value of Xuzhou City reached USD 66.6 billion in 2011, while the GDP of Xuzhou City in the same year was only USD 55 billion. The former is 1.21 times that of the latter.

At the provincial level, Ouyang [42] targeted Guizhou Province to measure the ecosystem value, which included the product value of Guizhou Province's ecosystem, the value of regulating services, and the cultural service of the ecosystem. The evaluation results show that the total value of ecosystem production in Guizhou Province in 2010 was USD 3108.09 billion and the per capita GEP was USD 8933.79, which equated to 4.3 times the province's GDP and GDP per capita. Wang [43] divided the value of Jiangsu's water re- 
sources ecosystem into three parts: ecological product value, ecological regulation function value, and ecological cultural value. Wang et al. selected the market and price data from authoritative literature and reported that that the GEP data of Jiangsu Province's water resources ecosystem in 2013 amounted to USD 86.79 billion, which was USD 27.57 billion more than the part included in the GDP.

Chinese researchers have generally accepted the accounting theory of GEP. The ecosystem value (GEP) includes not only the value of economic products but also the value of ecosystem services. From the results of GEP calculation, the value of ecosystem services accounts for a large proportion of GEP. This may indicate that a qualitative difference exists between the value of ecosystem services and the value of natural resource assets. Section 5 discusses the comparison of value of ecosystem services and value of natural resource assets.

\subsection{Literature Review of the Value of Natural Resources in National Economic Accounting}

China's discussion on asset valuation in national economic accounting can be traced back to the national economic accounting statistical report that was compiled by the National Bureau of Statistics in 1997 [44]. This study summarizes some recent views and practices about forest resources in China. Liu [45] explored the methods of transforming forest resources from physical to monetary quantities. Liu proposed three calculation methods: the market value method, the income capitalization value method, and the cost expense method. Liu stated that obtaining or searching for special original documents, physical quantity measurement technology, standardization of the measurement of physical quantity or value, and the extension of the scope of information disclosure will increase the verifiability of the fair value of forest land. Long and Fang [46] summarized a special investigation into the value of natural resources, such as forests, woodlands, and wetlands, which was organized by the special working group of the Forestry Department of Guizhou Province. The evaluation results show that the economic value of forestry natural resources assets in Baiyun District of Guizhou Province was USD 65,870.91 million. Su [47] proposed that the value of forest land resources should be divided into three aspects: economic benefit value, ecological benefit value, and social benefit value. Su suggested that the value calculation of forest land should rely on the current market value method, replacement cost method, and income capitalization method. The calculated formula should be expressed, as follows:

The commercial value of the forest $=$ the current capitalization price of the forest land rent + the present value of expected future profit of the main wood products and by-products + the capitalization price of estimated annual residual income from forest land tourism, animal husbandry.

A forest ecosystem provides humans with a continuous supply of wood products and services, such as water conservation, soil conservation, carbon fixation and oxygen release, forest nutrient accumulation, purification of the atmosphere, and biodiversity conservation. These services do not have mature market prices, and they require the assistance of professional institutions or experts. This indicates that the valuation process of ecosystem services is essentially different from that of natural resource assets.

The evaluation of ecosystem services provides the basis for the ecological compensation mechanism. Additionally, China is currently promoting the management policy of ecological function zone to integrate ecological damage loss and ecological protection values into social and economic management, which requires an ecological compensation mechanism. Therefore, the evaluation of ecosystem services has important practical significance.

In response to the ecological function zone policy, the Jiaokou County government in Northern China has carefully analyzed the natural resource asset management and ecological environment protection of the county and has tried to prepare a reporting system containing various natural resource assets. The case study in this paper is based on the GEP estimation of the forest ecosystem in Jiaokou County. 


\section{Methodology}

\subsection{Research Framework}

According to the GEP theory summarized above, ecosystem value is divided into natural resource asset value and ecosystem service value. The System of National Accounts (SNA) and System of Environmental-Economic Accounting (SEEA) are the two international accounting standards. The macro accounting tables of these two standards are the national balance sheet and natural resources balance sheet, respectively. The case study contained in this paper is based on the conceptual framework summarized in Figure 1.

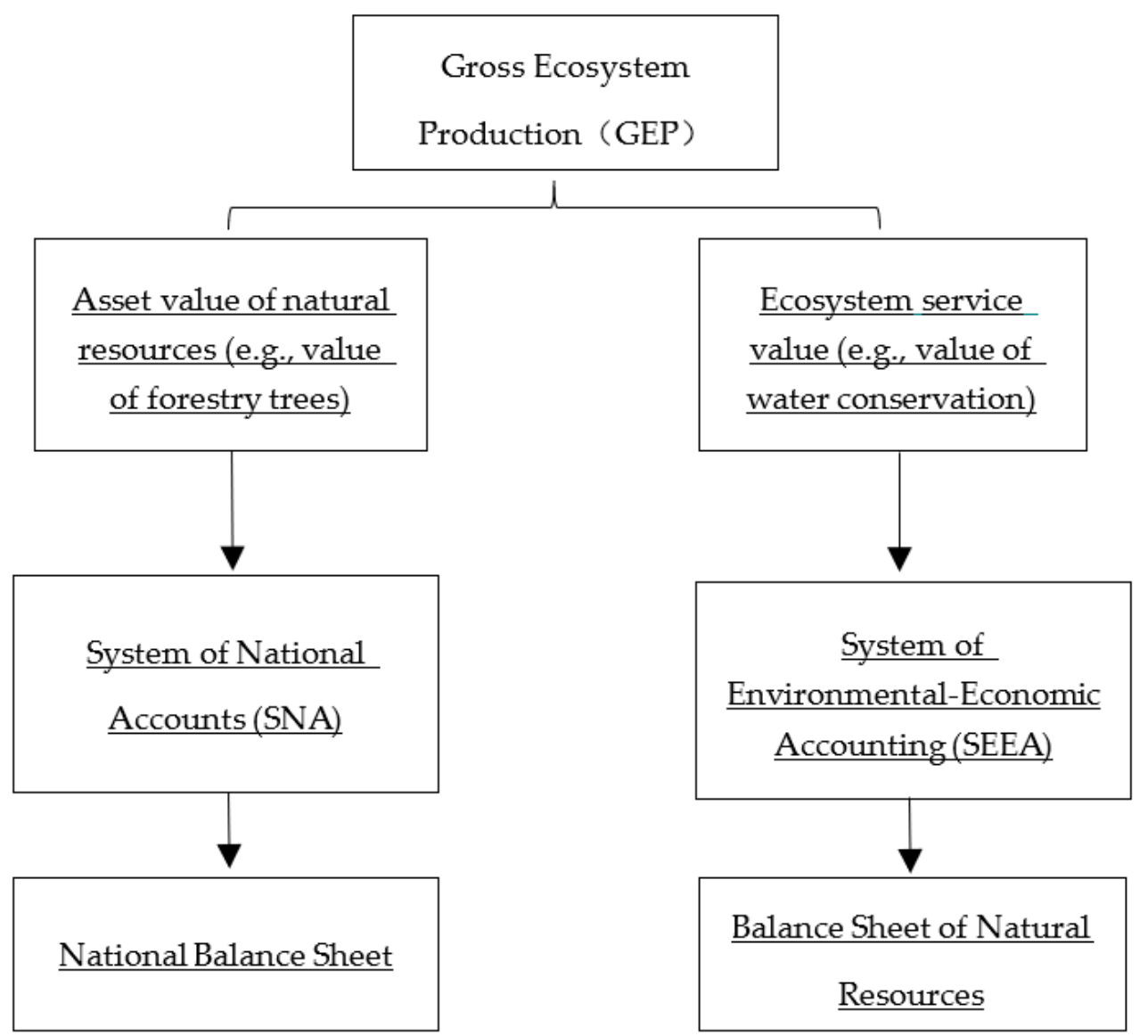

Figure 1. Framework for this research based on gross ecosystem production theory.

We first explored the difference and connection between the value of natural resource assets and the value of ecosystem services. The China Bureau of Statistics is promoting the compilation of a natural resources balance sheet, while the China Audit Office has been endorsing the audit of outgoing officials' natural resource asset management. Thus, we next discussed the relationship between these two practices and the above research framework and tried to determine whether the value of natural resources assets or ecosystem services should be involved in different practices.

The objective of this study was to analyze and compare the value of natural resources assets and the value of ecosystem services through one case study to fill the theoretical gap, necessitating a natural resources balance sheet and ecological compensation systems in China.

\subsection{Research Methods}

The government of Jiaokou County, Shanxi Province, Northern China, analyzed the management of natural resource assets and the protection of ecological environment. Following this, it decided to prepare a report system containing a number of natural 
resources assets. WUYIGE Certified Public Accountants LLP estimated the GEP value of the forest ecosystem. The case in this paper is based on the data analysis conducted in this practical work. We used several methods for fundamental information, which included text investigation and phenomenon observation, a semi-structured interview, in-depth observation, and open data collection.

We conducted qualitative and quantitative analyses. First, we selected each village in Jiaokou County as a unit and then interviewed the leader of each village. Information on the different types and areas of land in each village was collected through a questionnaire survey of the relevant person in charge. The purpose of this step was to accurately distinguish the land types in rural areas and accurately calculate the area of forest land. The determination of forest land type and the calculation of forest area formed the basis for the follow-up accounting of the economic value and ecological value of the forest resources. In terms of the value of forest resources assets, we collected the forestry business data that constituted economic income in rural areas of Jiaokou County. The cash flow discount method was used to discount forestry income to the current time point as the value of forest resources assets. In relation to the value of forest ecological services, this study issued a statistical questionnaire to the functional departments and institutions of the Jiaokou County government and collected various parameters of forest ecological services. At the same time, we conducted an exclusive interview with the heads of various functional departments and determined the pricing methods of different ecological services, which included the alternative cost method, market value method, and a prevention and control cost method. The value of forest ecological services was calculated as the related parameters multiplied by the unit price.

Based on the data of the audit report that the accounting firm issued, we compiled the relevant forms in the case and then compared and analyzed the forest asset value and ecological service value of the forest resources. Several certified public accountants signed the relevant audit reports; thus, the physical quantification and value accounting of forest resources were reliable.

\subsection{Data Collection}

In 2018, the accounting firm in the case, namely WUYIGE Certified Public Accountants LLP, surveyed different forest types in Jiaokou County and evaluated six services of forest ecosystem, including water conservation, soil conservation, carbon fixation and oxygen release, forest nutrients, air purification, and biodiversity. In physical quantity accounting, the data were obtained from questionnaires, unmanned aerial vehicles' data, and satellite mapping data. In terms of value accounting, the data were obtained from the existing data of 10 functional departments of the Jiaokou County government and two public institutions.

We adopted two methods: collecting data from the functional departments of the county government and interviewing the persons in charge. In this study, ten functional departments of the Jiaokou County government (Natural Resources Bureau, Environmental Protection Bureau, Forestry Bureau, Water Conservancy Bureau, Agricultural and Rural Bureau, Statistics Bureau, Finance Bureau, Housing and Urban Construction Bureau, Urban Management Bureau, and Transportation Bureau) and two public institutions (Agricultural Economic Service Center and the Public Service Center) were investigated, and data were obtained. Additionally, four towns and 381 villages were investigated, and all of the questionnaires were collected.

The audit methods, such as calculation, analysis, comparison, and field investigation, were used to further analyze the collected data to ensure the accuracy and rationality of the data. In the verification of forest land area, we compared the data from the questionnaire with the data from unmanned aerial vehicles and satellite mapping. All of the data errors were corrected. On the basis of the above work, we further analyzed the logical relationship of the natural resources balance sheet to perform a reasonable cross-check between the various statements of natural resources assets. 


\section{Case Description}

\subsection{Introduction of the Case Subject}

The case subject in this article is Jiaokou County, Shanxi Province, Northern China. The county's forest coverage rate is $42.41 \%$, and the forest greening rate is $63.77 \%$. Its forest resources are some of the important resources in the county. The county's ecological vegetation is vast, which is a valuable asset provided by nature. Through strict procedures, the county selected WUYIGE Certified Public Accountants LLP to prepare the natural resource balance sheet for the county. Table 2 presents the relevant land assets data of the natural resource balance sheet.

Table 2. A summary of land assets of Jiaokou County (2018).

\begin{tabular}{ccc}
\hline Land Type & Area (Unit: Hectare) & Value (Unit: USD 10,000) \\
\hline Farmland & 22,247 & $59,735.06$ \\
\hline Forest land & 91,144 & $315,225.30$ \\
\hline Husbandry land & 5020 & $13,352.85$ \\
\hline Residential land & 3057 & $15,665.73$ \\
\hline Total & 121,468 & $403,978.94$ \\
\hline
\end{tabular}

Jiaokou County's land area consisted of 91,144 hectares of forest land, 22,247 hectares of farmland, 5020 hectares of husbandry land, and 3057 hectares of residential land according to the evaluation report of WUYIGE Certified Public Accountants LLP in 2019. The forest land and farmland were the two largest types in the county. In the estimation of land resources in the county's natural resource value assessment in 2019, the farmland value and husbandry value were calculated by the land capitalization method (unit land income/yield $4 \%$ ). The construction land being traded was calculated by the fair market value or the price set by the relevant public sector. For forest land, such as orchard land, which has an important position in the county, the estimation method was consistent with the farmland. The total value of the forest land, namely the value of forest resources, was USD 3152.25 million.

However, most of the forest land in the county did not produce any economic crop and, thus, could not be seen as an asset. For example, oak was the main tree species in the forest area, which requires 80 years to grow to its full size and was then only 30 years old. The local government spent millions of dollars on the maintenance of the forest farm per year. Because of the important role of the ecosystem, most of the forest land in the county resides behind the red line for ecological protection and, thus, is strictly prohibited from development. Therefore, in the preparation of the forest land resource value table, the accounting firm participating in the compilation suggested that the county's 2018 forest resource value consisted of very little product value but a large amount of ecosystem service value. In reference to the ecosystem evaluation report of the county one year ago, the ecosystem services included water conservation, soil conservation, carbon fixation and oxygen release, forest nutrient accumulation, purification of the atmosphere, and biodiversity protection.

\subsection{Process and Content of Forest Ecosystem Evaluation}

The calculation process of the evaluation in the case presented was especially redundant and requires a considerable amount of space. Thus, Appendix A at the end of this paper summarizes the calculation process and its results.

According to the county's assessment report, the value of the forest ecosystem services in the county at the end of 2018 was USD 11,988.92 million dollars, and Table 3 presents the forest ecosystem services value corresponding to each town. 
Table 3. Forest ecological value of Jiaokou County (2018) (USD 10 000).

\begin{tabular}{cccccc}
\hline Value Type & Chengguan Town & Xicheng Town & Shuangta Town & Yangliupo Town & Total \\
\hline Water conservation & $128,010.34$ & $98,019.82$ & $17,810.36$ & $148,251.68$ & $392,092.20$ \\
\hline Soil conservation & $76,453.53$ & $58,541.84$ & $10,637.15$ & $88,542.56$ & $234,175.08$ \\
\hline Carbon fixation and oxygen release & $36,358.72$ & $27,840.52$ & 5058.67 & $42,107.85$ & $111,365.76$ \\
\hline Forest nutrients & 8169.93 & 6255.86 & 1136.70 & 9461.78 & $25,024.27$ \\
\hline Purifying the atmosphere & $109,551.90$ & $83,885.85$ & $15,242.19$ & $126,874.52$ & $335,554.46$ \\
\hline Biodiversity & $32,870.01$ & $25,169.15$ & 4573.28 & $38,067.50$ & $100,679.94$ \\
\hline Total & $391,414.43$ & $299,713.04$ & $54,458.35$ & $453,305.89$ & $1,198,891.71$ \\
\hline
\end{tabular}

The most valuable type of forest ecosystem services in the county was water conservation, while Yangliupo was the town with the greatest value of forest ecosystem services, as shown in Table 3, because Yangliupo Town owned the largest part of the forest land.

\subsection{Analysis of Calculation Process and Results}

The ecological value of the county's forest assessed in Table 3 was not the entire GEP value but only the value of the services provided by the forest ecosystem, according to the classification of Ouyang [39]. The value of the county's economic crops of forest land was calculated independently. Because the assessment of the value of forest ecosystem services was different from traditional economic crops in terms of characteristics and nature, the two were separated. The members of the report preparation group divided the evaluation into two parts: forest land with real income (mainly walnut trees) and forest land not providing income (such as Liaodong oak, cedar, birch, etc., which were classified as the ecological protection red line tree species). It was obvious that the calculation process required too much data and the complexity exceeded the scope of conventional knowledge and the practice of accounting and auditing. Additionally, the evaluation of forest ecosystem services involved expertise in environmental science and required expert participation.

Through the calculation of the ecosystem value, the originally imponderable assets formed the largest part of natural resource assets. Whether from the perspective of the calculation process or the calculation results, the ecosystem service value was obviously different from the traditional natural resource asset value. This study summarized the characteristics of ecosystem service value into four aspects: (1) the calculation results were uncertain; (2) the calculation process and results were based on a series of assumptions; (3) the forest ecosystem service was an important public item that was difficult to price; and (4) the volume and scale of ecosystem service value were huge compared to natural resource assets.

Firstly, the calculation results were uncertain because the value assessments of the six forest ecosystem services, in particular water conservation, soil conservation, carbon fixation and oxygen release, forest nutrient accumulation, purification of the atmosphere, and biodiversity conservation, were dependent on measurement parameters. For example, the following formula calculates the annual water regulation quantity value:

$$
\mathrm{U}_{\mathrm{adj}}=10 \times \mathrm{C}_{\text {adj }} \times \mathrm{A} \times(\mathrm{P}-\mathrm{E}-\mathrm{C}) \times \mathrm{F} \times \mathrm{d}
$$

where $U_{\text {adj }}$ is the annual forest water regulation quantity value (USD/year); $C_{a d j}$ is the reservoir storage capacity price (USD/cubic meter); $\mathrm{P}$ is the precipitation outside the forest (mm/year); $E$ is the stand evapotranspiration ( $\mathrm{mm} /$ year); $C$ is surface fast runoff $(\mathrm{mm} /$ year); $\mathrm{A}$ is stand area (hectare); $\mathrm{F}$ is the forest ecological function correction factor; and $\mathrm{d}$ is the discount rate.

Precipitation outside the forest (mm/year), stand evapotranspiration ( $\mathrm{mm} /$ year), surface fast runoff ( $\mathrm{mm} /$ year), and stand area (hectare) were all measured by relevant departments or agencies in the calculation of the annual forest water regulation quantity value, but the data of these measurements could not be $100 \%$ accurate. 
Secondly, the calculation process and results were based on a series of assumptions. For example, the assessment report clearly stated that the annual water regulation quantity value was determined according to the water storage cost of the reservoir project (instead of the engineering method). The whole forest was regarded as an artificial water reservoir, and water storage cost was the calculated value. However, this was only the calculation assumption of the cost method and did not necessarily represent the actual value that can be achieved. Additionally, the drought loss prevented by forest water storage was also an idea for calculating its value. The calculation results produced by different kinds of calculation logic, such as the cost and expense method, market value method, and opportunity cost, were often different.

Thirdly, forest ecosystem services are an important public item that are difficult to price. Public goods have two characteristics: the first is non-involvement, which means that one person consumed the goods without affecting the consumption of another, and the second is non-excludability, which means there is no reason to exclude other people from consuming these goods, such as fresh air or pollution-free water sources. Forest ecosystems provide the public with vital services in many kinds, such as conserving water sources, purifying the environment, etc. Private goods have market prices because they are exchanged in the market, but there is no market exchange for public goods and therefore no market price, which produces considerable difficulties in their valuation. Thus, the characteristic of uncertainty was prevalent in the calculation of the value of forest services mentioned above. With the popularization of GEP evaluation and the advancement of measurement technology, the calculation of the value of ecosystem service volume may also develop over time. However, the GEP value assessment will clearly remain uncertain for a long time.

Fourthly, the volume and scale of ecosystem services value were huge compared to natural resource assets. The value of forest ecosystem services was 3.80 times the value of all forest resources calculated according to the System of National Accounts (USD 11,988.92 million/USD 3152.25 million) and 2.97 times the value of total land resources of the county (USD 11,988.92 million/USD 4039.79 million). Additionally, according to GDP data of the county in 2018, the value of forest ecosystem services was 13.85 times the county's GDP (USD 11,988.92 million/USD 865.38 million). However, this characteristic is not unique to the county's forest ecosystem assessment. Domestically or abroad, the results of researchers show that the total value of a comprehensive ecosystem is often much larger than normal economic indicators. As mentioned in the previous sections of this paper, the calculation results by domestic researchers such as Zhiyun Ouyang of the total ecosystem production value of Guizhou Province or Liyan Wang of the ecosystem GDP of Inner Mongolia Aershan City show that the value of the ecosystem is much larger than the GDP by the System of National Accounts. Therefore, though the value of hundreds of billions of forest ecosystems in the county is much larger than forest resource asset, it is common and normal in the assessment of ecosystem values worldwide. This also showed that the forest ecosystem is a comprehensive ecosystem and that its contribution to human socioeconomic output is indirect but fundamental and decisive.

\section{Case Findings}

According to the analysis of the characteristics of the calculation process and results presented above, we summarized the research findings based on the case study and then compared and analyzed the value of forest ecosystem services and the value of natural resource assets by the System of National Accounts. We attempted to use our findings to explain the relationship between the two and, thus, provide a correct understanding of the ecosystem value. We tried to solve theoretical issues in the preparation of the balance sheet of natural resources and in the implementation of the ecological compensation system through such comparison and analysis. 


\subsection{Concept of Two Values Is Different}

The USD 11,988.92 million forest ecosystem value mentioned above is not the entire GEP value in the traditional sense-it is only the value of ecosystem services in GEP, and it does not include the product value of ecosystems. In the assessment report prepared by the county government, the forest land economic crops are separately valued as forest land resources, which can also be regarded as the value of natural resource assets in the forest ecosystem. Thus, there is an inclusive relationship between the ecosystem value (GEP) and the value of natural resources in the traditional System of National Accounts. The value of ecosystem (GEP) refers to the sum of the value of products and services that ecosystems provide to human beings. Additionally, the value of ecosystem services is only a possibility, which means that it can be considered as a contingent liability. Nevertheless, the forest land economic crops are traditional accounting assets. Their conceptual difference indicates the difference found in theoretical research as well as their practical application.

\subsection{Ecosystem Services Value Is Mandatory in Actual Implementation}

In China, the ecosystem services value is mostly used in relation to monetary fines for the violation of environmental protection regulations or as the calculation basis for the amount of compensation funds for inter-city and inter-provincial ecological benefits. Whereas the natural resource assets value mainly exists in contracts or agreements for the integration of other types of assets (production or living assets) in society, mutual exchange, etc., it is also used as the measurement basis for preparing the natural resources balance sheet. The application example of the ecosystem services value could be as small as "Shenzhen has a small car illegally parked in the green belt and was fined USD 501.62, covering an area of 64.6 square meters. It is punished by USD 7.76 per square meter" (for details, please access the link from 9 September 2019: http:/ / news.sina.com.cn/s/2019-0909/doc-iicezueu4437290.shtml) and as large as "Fujian Province successfully implemented a policy that the lower river regions compensate for regional forest ecological benefit in upstream areas" (for details, please refer to the Notice of the People's Government of Fujian Province on Implementing Compensation for Forest Ecological Benefits in the Upper Reaches of the Lower Reaches of the Yangtze River in 2007). The application example of the natural resource assets value can be the operation decision between different governments or enterprises or the execution of the actual business plan in which a certain amount of value is directly converted into a monetary amount. In summary, the ecosystem services value is often used in mandatory payments that are related to the Chinese government, and the recipient of the value paid will be the only one to benefit. Moreover, the natural resource assets value is market-based and fair value, which is reflected in the exchange of assets. Accordingly, only the natural resource assets value can be included into the balance sheet of natural resources.

\subsection{Natural Resource Assets Value Is an Accounting Asset, Whereas Ecosystem Services Value Is an Environmental Liability}

In the calculation process of Jiaokou County, the evaluation of natural resource assets was based on forest land economic crop products, with clear market price information and data, and the income capitalization method and the cost approximation method are both well-established value assessment methods in asset evaluation. However, the assessment of the value of forest ecosystem services had neither market information nor data, and the assessment methods were unconventional with greater uncertainty. Furthermore, the contribution of economic crop products to the social economy is direct. Therefore, it can be regarded as a traditional accounting asset, whereas the role of forest ecosystem services in the economy and society is indirect. In terms of forests, for example, biodiversity protection is reflected in the process of conserving water sources, purifying water quality, consolidating embankments, preventing soil erosion, reducing flood peaks, improving local climate, absorbing pollutants, and acting as a catalyst in the regulation of global climate change. It does not constitute the direct consumption of the economy and society. Therefore, 
if any forest ecosystem is somehow damaged, then there should be environmental liabilities or environmental protection expenditure. Subsequently, the value of forest ecosystem services can be the basis of liabilities or compulsory payment. The conclusion is also applicable to other ecosystems. We regarded the possibility of ecological service value damage as a contingent liability in the accounting confirmation and measurement.

\subsection{Natural Resource Assets Value and Ecosystem Services Value Should Be Used in Different Practical Applications}

When a fine is imposed or compensation fees are collected from enterprises, only the ecological protection price or the ecological compensation price involved in ecosystem services evaluation should be used, whereas the fair value and exchange price of natural resource assets should not. However, when preparing a natural resource balance sheet or a national balance sheet, it would be meaningless to involve ecosystem service values that are a number of times higher than the exchange value of ecological products in the market. Furthermore, the value of ecosystem services, the value of natural resources assets, and the gross domestic product (GDP) should not be compared using numbers: they must be treated separately. Otherwise, the significant difference between the value of ecosystem services and other kinds of values will be ignored and eventually lead to mistakes or misunderstandings in relevant work.

We suggest that the assessment of the value of ecosystem services, especially the assessment of the value of forest ecosystem services, is vital because it provides a pricing mechanism for environmental protection in addition to possible and common economic activities. Namely, it provides a crucial reference value for the ecological compensation mechanism. The practice of ecosystem services evaluation will strongly promote the construction of an ecological civilization in China. In addition, the assessment of the value of ecological products, in particular the value of natural resource assets, should be used in compiling a natural resource balance sheet and national balance sheet.

\section{Conclusions and Prospects}

\subsection{Conclusions}

In this study, we evaluated forest ecosystem services in Jiaokou County, Shanxi Province, Northern China. Our findings indicate that the county's forest ecosystem assessment value is only the value of ecosystem services from the perspective of traditional GEP theory. The data and indicators on which the assessment method relied are insufficiently marketized, and the assessment results have uncertainty. The forest ecosystem services value assessment results are large in terms of magnitude, being more than 13.85 times the county's GDP. The county's assessment results can provide a pricing basis for a forest ecosystem value compensation mechanism, but the characteristics shown above suggest that its role may be controversial and its reference significance may be limited. The assessment methods and results of the county's forest ecosystem are reasonable when considering existing research both domestically and abroad because the evaluation of a comprehensive ecosystem, such as the assessment of the value of a forest ecosystem, is inherently large and uncertain, which is common in assessment cases of any kind of ecosystem around the world.

\subsection{Shortcomings and Prospects}

This paper summarizes the evaluation methods of existing ecosystem assessment cases, but the specific case only involved the evaluation of the forest ecosystem in one county in Northern China. The analysis of how the domestic cases realize the marketization of the value is insufficient, which is often the key in achieving a fair assessment. We suggest that the current ecosystem value assessment provides limited reference value for the pricing of ecological compensation practices. Additionally, the existing domestic ecological value compensation practices do not yet fully use the ecological value assessment results. In 
future research, the marketization approach of ecosystem value assessment can be explored to provide more relevant pricing reference for the practice of ecological value compensation.

Author Contributions: J.G., conceptualization, methodology, formal analysis, supervision, validation, visualization, and funding acquisition; C.L., writing-original draft preparation, review, and editing. All authors have read and agreed to the published version of the manuscript.

Funding: This study was funded by the project of National Social Science Fund Key Project Research on Natural Resource Asset Audit and Environmental Responsibility Audit under the New Environment (Approval No.: 15AZD060).

Institutional Review Board Statement: Not applicable.

Informed Consent Statement: Informed consent was obtained from all the subjects involved in the study.

Data Availability Statement: Not applicable.

Acknowledgments: This study was supported by the National Social Science Fund Key Project Research on Natural Resource Asset Audit and Environmental Responsibility Audit under the New Environment (15AZD060).

Conflicts of Interest: The authors declare no conflict of interest.

\section{Appendix A}

The calculation of the value of the forest ecosystem would have disrupted the flow of the main text but remains crucial to understanding and reproducing the research. Thus, it is shown in the table below. 
Table A1. Forest ecosystem value calculation (2018).

\begin{tabular}{|c|c|c|c|c|}
\hline Function & Value Formed & $\begin{array}{l}\text { Calculation Reason and } \\
\text { Basis }\end{array}$ & Calculation Formula & Explanation of Symbols \\
\hline \multirow{2}{*}{$\begin{array}{l}\text { Water conservation } \\
\text { Value = USD } \\
3920.92 \text { million }\end{array}$} & $\begin{array}{l}\text { Value of annual water } \\
\text { adjustment amount } \\
\text { (alternative } \\
\text { engineering method) }\end{array}$ & $\begin{array}{l}\text { Water storage cost of the } \\
\text { reservoir project }\end{array}$ & $\begin{aligned} \mathrm{G}_{\mathrm{adj}}=10 \times & \mathrm{A} \times(\mathrm{P}-\mathrm{E}-\mathrm{C}) \\
& \times \mathrm{F}\end{aligned}$ & $\begin{array}{c}\mathrm{G}_{\text {adj }} \text { is the annual water adjustment volume (cubic meters/year); } P \text { is the precipitation ( } \mathrm{mm} / \text { year); } \mathrm{E} \text { is } \\
\text { evapotranspiration ( } \mathrm{mm} \text { /year); } \mathrm{C} \text { is surface fast runoff ( } \mathrm{mm} / \text { year); } \mathrm{A} \text { is stand area (hectare); } \mathrm{F} \text { is the } \\
\text { correction factor for forest ecological function }\end{array}$ \\
\hline & $\begin{array}{l}\text { Value of annual } \\
\text { purification of water } \\
\quad \text { (alternative } \\
\text { engineering method) }\end{array}$ & $\begin{array}{l}\text { Cost of purifying water } \\
\text { quality projects }\end{array}$ & $\begin{array}{l}\mathrm{U}_{\text {pur }}=10 \times \mathrm{K}_{\text {pur }} \times \mathrm{A} \times(\mathrm{P}- \\
\mathrm{E}-\mathrm{C}) \times \mathrm{F} \times \mathrm{D}\end{array}$ & $\begin{array}{l}\mathrm{U}_{\text {pur }} \text { is the value of water purification of stand (USD/year); } \mathrm{K}_{\text {pur }} \text { is the water purification cost } \\
\text { (USD/cubic meter); P is precipitation (mm/year); } \mathrm{E} \text { is stand evapotranspiration (mm/year); } \mathrm{C} \text { is } \\
\text { surface fast runoff (mm/year); A is stand area (hectare); } \mathrm{F} \text { is the correction factor for forest ecological } \\
\text { function; } d \text { is the discount rate }\end{array}$ \\
\hline \multirow[b]{2}{*}{$\begin{array}{l}\text { Soil conservation } \\
\text { Value = USD } \\
2341.75 \text { million }\end{array}$} & $\begin{array}{l}\text { Value of annual soil } \\
\text { conservation }\end{array}$ & Water storage cost & $\begin{aligned} \mathrm{U}_{\mathrm{con}}= & \mathrm{A} \times \mathrm{C} \times\left(\mathrm{X}_{2}-\mathrm{X}_{1}\right) \times \\
& \mathrm{F} \times \mathrm{D} / \mathrm{p}\end{aligned}$ & $\begin{array}{l}\mathrm{U}_{\text {con }} \text { is the annual soil conservation (USD/year); } \mathrm{X}_{1} \text { is the soil erosion modulus of forest land (ton/(ha } \\
\text { year)); } \mathrm{X}_{2} \text { is the soil erosion modulus without forest land (ton/(ha year)); } \mathrm{C}_{ \pm} \text {is the cost of excavating } \\
\text { and transporting a unit volume of earthwork (USD/cubic meter); } \rho \text { is the soil bulk density }(\mathrm{g} / \mathrm{cm} 3) ; \mathrm{A} \\
\text { is the stand area (hectare); } \mathrm{F} \text { is the correction factor for forest ecological function; } \mathrm{d} \text { is the discount rate }\end{array}$ \\
\hline & $\begin{array}{l}\text { Value of annual } \\
\text { fertilizer maintenance }\end{array}$ & $\begin{array}{l}\text { Value of the synthesis of } \\
\text { diammonium phosphate } \\
\text { fertilizer and potassium } \\
\text { chloride fertilizer converted } \\
\text { from the amount of nitrogen, } \\
\text { phosphorus, and potassium in } \\
\text { soil fixing }\end{array}$ & $\begin{array}{l}\mathrm{U}_{\text {fer }}=\mathrm{A} \times\left(\mathrm{X}_{1}-\mathrm{X}_{2}\right) \times(\mathrm{N} \\
\times \mathrm{C}_{1} / \mathrm{R}_{1}+\mathrm{P} \times \mathrm{C}_{1} / \mathrm{R}_{2}+\mathrm{K} \\
\left.\quad \times \mathrm{C}_{2} / \mathrm{R}_{3}+\mathrm{M} \times \mathrm{C}_{3}\right) \times \\
\quad \mathrm{F} \times \mathrm{D}\end{array}$ & $\begin{array}{l}\mathrm{U}_{\text {fer }} \text { is annual fertilizer maintenance value (USD/year); } \mathrm{X}_{1} \text { is soil erosion modulus of forest land } \\
\text { (ton/(ha year)); } \mathrm{X}_{2} \text { is soil erosion modulus without forest land (ton/(ha year)); } \mathrm{N} \text { is the average soil } \\
\text { nitrogen content of forest land (\%); } \mathrm{P} \text { is the average soil phosphorous content of forest land (\%); } \mathrm{K} \text { is the } \\
\text { average soil potassium content of forest land (\%); M is forest soil organic matter content }(\%) ; \mathrm{R}_{1} \text { is the } \\
\text { nitrogen content of diammonium phosphate fertilizer (\%); } \mathrm{R}_{2} \text { is the phosphorous content of } \\
\text { diammonium phosphate fertilizer (\%); } \mathrm{R}_{3} \text { is the potassium content of potassium chloride fertilizer (\%); } \\
\mathrm{C}_{1} \text { is the diammonium phosphate fertilizer price (USD/ton); } \mathrm{C}_{2} \text { is potassium chloride fertilizer price } \\
\text { (USD/ton); } C_{3} \text { is organic matter price (USD/ton); A is stand area (hectare); } \mathrm{F} \text { is the correction factor for } \\
\text { forest ecological function }\end{array}$ \\
\hline \multirow[t]{2}{*}{$\begin{array}{l}\text { Carbon fixation and } \\
\text { oxygen release } \\
\text { service } \\
\text { Value = USD } \\
1113.66 \text { million }\end{array}$} & $\begin{array}{c}\text { Annual carbon } \\
\text { sequestration value }\end{array}$ & $\begin{array}{l}\text { Forest vegetation and soil } \\
\text { annual carbon } \\
\text { sequestration value }\end{array}$ & $\begin{array}{l}\mathrm{U}_{\mathrm{car}}=\mathrm{A} \times \mathrm{C}_{\mathrm{car}} \times(1.63 \times \\
\left.\mathrm{R}_{\mathrm{car}} \times \mathrm{B}_{\mathrm{car}}+\mathrm{F}_{\mathrm{car}}\right) \times \mathrm{F} \times \mathrm{D}\end{array}$ & $\begin{array}{l}\mathrm{U}_{\text {car }} \text { is stand carbon fixation value (dollars/year); } \mathrm{B}_{\mathrm{car}} \text { is stand net productivity (ton/(ha years)); } \mathrm{F}_{\mathrm{car}} \text { is } \\
\text { annual carbon sequestration per unit area of forest soil (ton/(ha year)); } \mathrm{C}_{\text {car }} \text { is carbon sequestration } \\
\text { price (dollars/ton, table attached); } \mathrm{R}_{\mathrm{car}} \text { is the carbon content of carbon dioxide which is } 27.27 \% \text {; } \mathrm{A} \text { is } \\
\text { stand area (hectare); } \mathrm{F} \text { is correction factor for forest ecological function; } \mathrm{d} \text { is discount rate. The formula } \\
\text { derives the potential annual carbon sequestration value of the forest and then subtracts the carbon loss } \\
\text { caused by the annual forest harvesting consumption, which is the actual annual carbon sequestration } \\
\text { value of the forest. }\end{array}$ \\
\hline & $\begin{array}{l}\text { Annual oxygen } \\
\text { release value }\end{array}$ & $\begin{array}{l}\text { Annual oxygen release value } \\
\text { of forest vegetation }\end{array}$ & $\begin{aligned} \mathrm{U}_{\text {oxy }}= & 1.19 \times \mathrm{C}_{\text {oxy }} \times \mathrm{A} \times \\
\mathrm{B}_{\text {oxy }} & \times \mathrm{F} \times \mathrm{D}\end{aligned}$ & $\begin{array}{c}\mathrm{U}_{\text {oxy }} \text { is annual oxygen release value (USD/year); } \mathrm{B}_{\text {oxy }} \text { is annual net productivity of forests } \\
\text { (ton/(ha year)); } \mathrm{C}_{\text {oxy }} \text { is price of oxygen production (USD/ton); } \mathrm{A} \text { is stand area (hectare); } \mathrm{F} \text { is the } \\
\text { correction factor for forest ecological function; } \mathrm{D} \text { is the discount rate }\end{array}$ \\
\hline $\begin{array}{l}\text { Cumulative } \\
\text { nutrient service } \\
\text { Value }=250.24 \\
\text { million dollars }\end{array}$ & $\begin{array}{l}\text { Accumulating } \\
\text { nutrient value }\end{array}$ & $\begin{array}{l}\text { The forest continuously } \\
\text { absorbs nutrients from the } \\
\text { surrounding environment } \\
\text { during its growth }\end{array}$ & $\begin{array}{c}\mathrm{U}_{\text {nut }}= \\
\mathrm{A} \times \mathrm{B} \times\left(\mathrm{N}_{\text {nut }} \times \mathrm{C}_{1} \times \mathrm{R}_{1}+\right. \\
\mathrm{P}_{\text {nut }} \times \mathrm{C}_{1} \times \mathrm{R}_{2}+\mathrm{K}_{\text {nut }} \times \mathrm{C}_{2} \\
\left.\times \mathrm{R}_{3}\right) \times \mathrm{F} \times \mathrm{D}\end{array}$ & 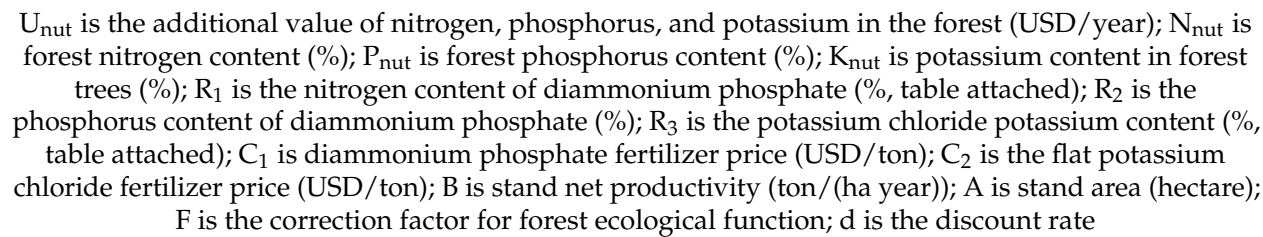 \\
\hline
\end{tabular}


Table A1. Cont.

\begin{tabular}{|c|c|c|c|c|}
\hline Function & Value Formed & $\begin{array}{l}\text { Calculation Reason and } \\
\text { Basis }\end{array}$ & Calculation Formula & Explanation of Symbols \\
\hline \multirow{6}{*}{$\begin{array}{l}\text { Purifying the } \\
\text { atmospheric } \\
\text { environment } \\
\text { Value = USD } \\
3355.54 \text { million }\end{array}$} & $\begin{array}{l}\text { 1. Annual negative } \\
\text { ion value }\end{array}$ & $\begin{array}{l}\text { Studies have shown that } \\
\text { negative ions in the air greater } \\
\text { than } 600 / \mathrm{cm}^{3} \text { are beneficial to } \\
\text { human health }\end{array}$ & $\begin{array}{c}\mathrm{U}_{\text {ion }}= \\
5.256 \times 10^{15} \times \mathrm{A} \times \mathrm{H} \times \mathrm{K}_{\text {ion }} \\
\left(\mathrm{Q}_{\text {ion }}-600\right) \times \mathrm{F} / \mathrm{L} \times \mathrm{D}\end{array}$ & $\begin{array}{l}\mathrm{U}_{\mathrm{ion}} \text { is negative ion value provided by the stand (USD/year); } \mathrm{K}_{\text {ion }} \text { is negative ion production cost } \\
\text { (USD/piece, table attached); } \mathrm{Q}_{\text {ion }} \text { is stand negative ion concentration (pieces/cubic centimeter); } \mathrm{L} \text { is } \\
\text { negative ion lifetime (minutes); } \mathrm{H} \text { is stand height }(\mathrm{m}) ; \mathrm{A} \text { is stand area (hectare); } \mathrm{F} \text { is the correction } \\
\text { factor for forest ecological function; } \mathrm{d} \text { is the discount rate }\end{array}$ \\
\hline & $\begin{array}{l}\text { 2. Annual absorption } \\
\text { of sulfur dioxide } \\
\text { value }\end{array}$ & $\begin{array}{l}\text { The ability of forests to absorb } \\
\text { sulfur dioxide pollutants }\end{array}$ & $\begin{array}{c}\mathrm{U}_{\text {sul }}=\mathrm{K}_{\text {sul }} \times \underset{\mathrm{D}}{\mathrm{Q}_{\text {sul }}} \times \mathrm{A} \times \mathrm{F} \times \\
\end{array}$ & $\begin{array}{l}\mathrm{U}_{\text {sul }} \text { is the annual absorption of sulfur dioxide value (USD/year); } \mathrm{K}_{\text {sul }} \text { is sulfur dioxide treatment } \\
\text { costs (USD } / \mathrm{kg}) ; \mathrm{Q}_{\text {sul }} \text { is the annual absorption of sulfur dioxide per unit area }(\mathrm{kg} / \text { (ha years)); } \mathrm{A} \text { is } \\
\text { stand area (hectare); } \mathrm{F} \text { is the correction factor for forest ecological function; } \mathrm{d} \text { is the discount rate }\end{array}$ \\
\hline & $\begin{array}{l}\text { 4. Annual absorption } \\
\text { of nitrogen oxides } \\
\text { value }\end{array}$ & $\begin{array}{l}\text { The ability of forests to absorb } \\
\text { carbon oxides }\end{array}$ & $\begin{array}{c}\mathrm{U}_{\text {nit }}=\mathrm{K}_{\text {nit }} \times \underset{\mathrm{D}}{\mathrm{Q}_{\text {nit }}} \times \mathrm{A} \times \mathrm{F} \times \\
\end{array}$ & $\begin{array}{l}\mathrm{U}_{\text {nit }} \text { is the annual absorption of nitrogen oxides in forest stands (USD/year); } \mathrm{Q}_{\text {nit }} \text { is annual } \\
\text { absorption of nitrogen oxides by unit area (kg/(ha } \cdot \text { year)); } K_{\text {nit }} \text { is nitrogen oxides treatment costs } \\
\text { (USD/kg); A is stand area (hectare); } F \text { is the correction factor for forest ecological function; } d \text { is the } \\
\text { discount rate }\end{array}$ \\
\hline & $\begin{array}{l}\text { 5. Annual } \\
\text { dust-retention value }\end{array}$ & $\begin{array}{l}\text { Calculating the value of } \\
\text { decomposition and dust } \\
\text { cleaning cost of forest land by } \\
\text { health hazard loss method }\end{array}$ & $\begin{array}{c}\mathrm{U}_{\text {dus }}= \\
\left(\mathrm{Q}_{\text {dus }}-\mathrm{Q}_{\mathrm{pM} 10}-\mathrm{Q}_{\mathrm{pm} 2.5}\right) \times \\
\mathrm{K}_{\mathrm{dus}} \times \mathrm{F} \times \mathrm{D}+\mathrm{U}_{\mathrm{pm} 10}+ \\
\mathrm{U}_{\mathrm{pm} 2.5}\end{array}$ & 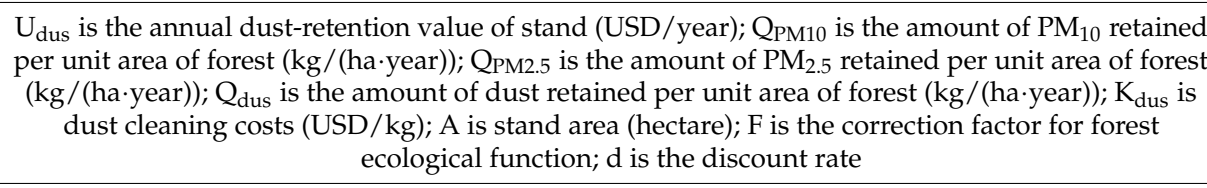 \\
\hline & $\begin{array}{l}\text { 6. Annual } \mathrm{PM}_{10} \\
\text { retention value }\end{array}$ & $\begin{array}{l}\text { Calculating the value of } \\
\text { decomposition and delay of } \\
\mathrm{PM}_{10} \text { in forest land by health } \\
\text { hazard loss method }\end{array}$ & $\begin{array}{l}\mathrm{U}_{\mathrm{pm} 10}=10 \times \mathrm{C}_{\mathrm{pm} 10} \times \mathrm{Q}_{\mathrm{pm} 10} \\
\quad \times \mathrm{A} \times \mathrm{n} \times \mathrm{F} \times \mathrm{LAI} \times \mathrm{d}\end{array}$ & $\begin{array}{l}\mathrm{U}_{\mathrm{PM} 10} \text { is the annual value of } \mathrm{PM}_{10} \text { retention of stand (USD/year); } \mathrm{C}_{\mathrm{PM} 10} \text { is health damage } \\
\text { economic loss caused by } \mathrm{PM}_{10} \text { (cost of treatment of upper respiratory tract disease) }(\mathrm{USD} / \mathrm{kg}) \text {; } \\
\mathrm{Q}_{\mathrm{PM} 10} \text { is the amount of } \mathrm{PM}_{10} \text { retained by unit leaf area of the stand }\left(\mathrm{g} / \mathrm{m}^{2}\right) ; \mathrm{A} \text { is stand area } \\
\text { (hectare); } \mathrm{n} \text { is number of elutions; } \mathrm{F} \text { is the correction factor for forest ecological function; } \mathrm{LAI} \text { is the } \\
\text { leaf area index; } \mathrm{d} \text { is the discount rate }\end{array}$ \\
\hline & $\begin{array}{l}\text { 7. Annual } \mathrm{PM}_{2.5} \\
\text { retention value }\end{array}$ & $\begin{array}{l}\text { Calculating the value of } \\
\text { decomposing delayed } \mathrm{PM}_{2.5} \\
\text { in forest land by the health } \\
\text { hazard loss method }\end{array}$ & $\begin{array}{c}\mathrm{U}_{\mathrm{pm} 2.5}=10 \times \mathrm{C}_{\mathrm{pm} 2.5} \times \mathrm{Q}_{\mathrm{pm} 2.5} \\
\times \mathrm{A} \times \mathrm{n} \times \mathrm{F} \times \mathrm{LAI} \times \mathrm{d}\end{array}$ & $\begin{array}{l}\mathrm{U}_{\mathrm{PM} 2.5} \text { is the annual value of } \mathrm{PM}_{2.5} \text { retention of stand (USD/year); } \mathrm{C}_{\mathrm{PM} 2.5} \text { is health damage } \\
\text { economic loss caused by } \mathrm{PM}_{2.5}(\text { cost of treatment of upper respiratory tract disease) }(\mathrm{USD} / \mathrm{kg}) \text {; } \\
\mathrm{Q}_{\mathrm{PM} 2.5} \text { is the amount of } \mathrm{PM}_{2.5} \text { retained by unit leaf area of the stand }\left(\mathrm{g} / \mathrm{m}^{2}\right) ; \mathrm{A} \text { is stand area } \\
\text { (hectare); } \mathrm{n} \text { is number of elutions; } \mathrm{F} \text { is the correction factor for forest ecological function; } \mathrm{LAI} \text { is the } \\
\text { leaf area index; } \mathrm{d} \text { is the discount rate }\end{array}$ \\
\hline $\begin{array}{l}\text { Biodiversity } \\
\text { protection } \\
\text { Value }=\text { USD } \\
1006.80 \text { million }\end{array}$ & $\begin{array}{l}\text { Value of biodiversity } \\
\text { conservation }\end{array}$ & $\begin{array}{l}\text { To facilitate the rational use of } \\
\text { biological resources and the } \\
\text { rational allocation of } \\
\text { protection work in } \\
\text { relevant departments }\end{array}$ & $\begin{array}{l}\mathrm{U}_{\text {total }}=\left(1+0.1 \sum \mathrm{E}_{\mathrm{m}}+0.1 \sum \mathrm{B}_{\mathrm{n}}\right. \\
\left.\quad+0.1 \sum \mathrm{O}_{\mathrm{r}}\right) \times \mathrm{S}_{1} \times \mathrm{A} \times \mathrm{D} \\
\quad\left(\sum \mathrm{m}=1 \sum \mathrm{n}=1 \sum \mathrm{r}=1\right)\end{array}$ & $\begin{array}{l}\mathrm{U}_{\text {total }} \text { is the annual value of stand biodiversity conservation (USD/year); } \mathrm{E}_{\mathrm{m}} \text { is the endangered } \\
\text { score of species } \mathrm{m} \text { in stand or area; Bn is the endemic species of species } \mathrm{n} \text { in the forest or region } \\
\text { assessed; } \mathrm{O}_{\mathrm{r}} \text { is the ancient tree age index of species } \mathrm{r} \text { in stand (or region) assessed; } \mathrm{x} \text { is the number } \\
\text { of endangered index species; } \mathrm{y} \text { is the number of endemic species; } \mathrm{S}_{1} \text { is the amount of conservation } \\
\text { value per unit area of species diversity (USD/(ha-year)); } \mathrm{A} \text { is stand area (hectare); } \mathrm{d} \text { is discount rate }\end{array}$ \\
\hline
\end{tabular}

Summarizing the above items, the total value of forest ecosystems is USD 11,988.92 million. 


\section{References}

1. Xianqiang, M. Theoretical Discussion on Ecological Compensation. Chinas Popul. Resour. Environ. 2002, 4, 38-40.

2. Westman, W.E. How much are nature's services worth. Science 1997, 197, 960-964. [CrossRef] [PubMed]

3. Ehrlich, P.R.; Mooney, H.A. Extinction, substitution and ecosystem services. Bioscience 1983, 33, 248-254. [CrossRef]

4. Braat, L.C. The value of the ecosystem services concept in economic and biodiversity policy. Ecosyst. Serv. 2013, 4, $22-26$.

5. Daily, G.C. Nature's Services: Societal Dependence on Natural Ecosystems. Popul. Environ. 1999, 20, $277-278$.

6. Costanza, R.; d'Arge, R.; de Groot, R.; Farber, S.; Grasso, M.; Hannon, B.; Limburg, K.; Naeem, S.; Oneill, R.V.; Paruelo, J.; et al. The value of the world's ecosystem services and natural capital. Nature 1997, 387, 253-260. [CrossRef]

7. Stavins, R.N. What can we learn from the Grand Policy Experiment? Lessons from SO2 allowance trading. J. Econ. Perspect. 1998, 12, 69-88.

8. Balmford, A. Economic Reasons for Conserving Wild Nature. Science 2002, 297, 950-953. [CrossRef]

9. Bayon, R. Making Environmental markets work: Lessons from early experience with sulfur, carbon, wetlands and other related markets. In Forest Trends; Katoomba Group Meeting: Locarno, Switzerland, 2003.

10. Wunder, S. Payments for environmental services: Some nuts and bolts. Occas. Pap. 2005, 12, 16-20.

11. Clarkson, B.R.; Ausseil, A.E.; Gerbeaux, P. Wetland ecosystem services. Dymond. In Ecosystem Services in New Zealand: Conditions and Trends; Dymond, J.R., Ed.; Manaaki Whenua Press: Lincoln, New Zealand, 2013; pp. 192-202.

12. Mitsch, W.J.; Gosselink, J.G. The value of wetlands: Importance of scale and landscape setting. Ecol. Econ. 2000, 35, 25-33. [CrossRef]

13. Mitsch, W.J.; Gosselink, J.G.; Anderson, C.J.; Zhang, L. Wetland Ecosystems; John Wiley and Sons: Hoboken, NJ, USA, 2009.

14. Mondal, B.; Dolui, G.; Pramanik, M.; Maity, S.; Biswas, S.S.; Pal, R. Urban expansion and wetland shrinkage estimation using a GIS-based model in the East Kolkata Wetland. Ecol. Indic. 2017, 83, 62-73. [CrossRef]

15. Shi, F.; Weaver, D.; Zhao, Y.; Huang, M.; Tang, C.; Liu, Y. Toward an ecological civilization: Mass comprehensive ecotourism indications among domestic visitors to a Chinese wetland protected area. Tour. Manag. 2019, 70, 59-68. [CrossRef]

16. Brown, G.; Schebella, M.F.; Weber, D. Using participatory GIS to measure physical activity and urban park benefits. Landsc. Urban Plan. 2014, 121, 34-44. [CrossRef]

17. Kaplan, R.; Kaplan, S. The Experience of Nature: A Psychological Perspective. Camb. Univ. Press 1989, 32, 180-200.

18. Chaudhry, P.; Bagra, K.; Singh, B. Urban greenery status of some Indian cities: A short communication. Int. J. Environ. Sci. Dev. 2011, 2, 98-101. [CrossRef]

19. Wu, J.; Plantinga, A.J. The influence of public open space on urban spatial structure. J. Environ. Econ. Manag. 2003, 46, 288-309. [CrossRef]

20. Haipeng, Z.; Xuxuan, X. Combining stated preference and revealed preference methods for the valuation of non-market goods. Chin. J. Popul. Resour. Environ. 2012, 10, 121-126. [CrossRef]

21. Louviere, J.; Hensher, D. Design and analysis of simulated choice or allocation experiments in travel choice modeling. Development 1982, 2, 15-20.

22. Louviere, J.; Woodworth, G. Design and analysis of simulated consumer choice or allocation experiments: An approach based on aggregate data. J. Mark. Res. 1983, 20, 350-367. [CrossRef]

23. Boxall, P.C.; Adamowicz, W.L.; Swait, J.; Williams, M.; Louviere, J. A comparison of stated preference methods for environmental valuation. Ecol. Econ. 1996, 18, 243-253. [CrossRef]

24. Taylor, T.; Longo, A. Valuation of Marine Ecosystem Threshold Effects: Application of Choice Experiments to Value Algal Bloom in the Black Sea Coast of Bulgaria. Dep. Econ. 2009, 15, 45-50.

25. Alvarez-Farizo, B.; Gil, J.M.; Howard, B.J. Impacts from restoration strategies: Assessment through valuation workshops. Ecol. Econ. 2009, 68, 787-797. [CrossRef]

26. Hoehn, J.; Lupi, F.; Kaplowitz, M. Stated choice experiments with complex ecosystem changes: The effect of information formats on estimated variances and choice parameters. J. Agric. Resour. Econ. 2010, 35, 568-590.

27. Broadbent, C.D. Evaluating mitigation and calibration techniques for hypothetical bias in choice experiments. J. Environ. Plan. Manag. 2013, 12, 1831-1848. [CrossRef]

28. Vollmer, D.; Ryffel, A.N.; Djaja, K.; Grêt-Regamey, A. Determining Demand for Riparian Ecosystem Services: A Spatially Explicit Discrete Choice Experiment in Jakarta, Indonesia. SSRN Electron. J. 2013, 12, 20-25. [CrossRef]

29. Hainmueller, J.; Hopkins, D.J.; Yamamoto, T. Causal inference in conjoint analysis: Understanding multidimensional choices via stated preference experiments. Politi. Anal. 2014, 22, 1-30. [CrossRef]

30. Hanley, N.; Wright, R.E.; Adamowicz, V. Using choice experiments to value the environment. Environ. Resour. Econ. 1998, 11, 413-428. [CrossRef]

31. Stevens, T.H.; Belkner, R.; Dennis, D. Comparison of contingent valuation and conjoint analysis in ecosystem management. Ecol. Econ. 2000, 32, 63-74. [CrossRef]

32. Fioramonti, L. How Numbers Rule the World: The Use and Abuse of Statistics in Global Politics; Zed Books: London, UK, 2014.

33. Kent, F.K. Integrating property value and local recreation models to value ecosystem services in urban watersheds. Land Econ. 2012, 84, 361-381.

34. Boumans, R.; Roman, J.; Altman, I.; Kaufman, L. The Multiscale Integrated Model of Ecosystem Services (MIMES): Simulating the interactions of coupled human and natural systems. Ecosyst. Serv. 2015, 12, 30-41. [CrossRef] 
35. Schmidt, S.; Manceur, A.M.; Seppelt, R. Uncertainty of monetary valued ecosystem services-value transfer functions for global mapping. PLoS ONE 2016, 11, 1-22. [CrossRef]

36. Divya, S.; Arnab, J. Evaluating the cultural ecosystem services of India: Comparison of budget allocations to improve the use value of recreational open spaces. Ecosyst. Serv. 2019, 38, 1-10.

37. Lilei, Z.; Dongjie, G.; Xiaoyong, H.; Xingzhong, Y.; Mengjie, Z. Evaluation of the cultural ecosystem services of wetland park. Ecol. Indic. 2020, 114, 1-13.

38. David, C.; Frances, R.; Tasman, P.; Crowe, J.B. Evaluating and communicating cultural ecosystem services. Ecosyst. Serv. 2020, 42, $1-10$.

39. Liyan, W.; Wei, X.; Zhiyun, O.Y. National Key Ecological Function District County Ecosystem GDP Calculation Research. Chin. Popul. Resour. Environ. 2017, 27, 146-153.

40. Zhuoga, B.M.; Wei, X.; Zhiyun, O.Y.; Liyan, W. Research on the accounting of ecosystem GDP in Ganzi Tibetan Autonomous Prefecture. Acta Ecol. Sin. 2017, 37, 6302-6312.

41. Dan, J.; Zhengfu, Z. Research on Xuzhou City Ecological Civilization Accounting Method Based on Emergy and GEP. China Land Sci. 2017, 27, 89-93.

42. Zhiyun, O.Y.; Chunquan, Z.; Guangbin, Y.; Weihua, X.; Hu, Z.; Wei, Z.; Wei, X. Ecosystem GDP Calculation: Concepts, Accounting Methods and Case Studies. Acta Ecol. Sin. 2013, 33, 6747-6761.

43. Baogan, W.; Wei, L. GEP accounting system exploration-Taking Jiangsu Province water resources ecosystem as an example. Water Conserv. Econ. 2015, 33, 14-18.

44. Qiang, L.; Xianchun, X. Revision of the statistical reporting system for national economic accounting. China Stat. 1997, 187, 8-11.

45. Meijuan, L. Research on Fair Value Measurement of Forest Natural Capital; Nanjing Forestry University: Nanjing, China, 2009.

46. Qide, L.; Linna, F. Evaluation of the value of forestry natural resources assets in Baiyun District, Guizhou Province. China Collect. Econ. 2016, 33, 15-18.

47. Jianlan, S. Basic model construction of forestry commercial value assessment. Green China 2005, 12, 52-55. 